\title{
The Relationship between Literacy Level and Coronary Risk Factors in Diabetic Patients
}

\section{Khademi $\mathbf{M}^{1}$ and Jahanlou $\mathrm{AS}^{2}$}

${ }^{1}$ Department of Internal Medicine, Hormozgan University of Medical Sciences, Bandar Abbas, Iran

${ }^{2}$ Assistant Professor, Health Education Department, Hormozgan University of Medical Sciences; Bandarabbas, Iran

${ }^{2}$ Visiting Scholar, College of Education, Texas A\&M university-Corpus Christi, USA

\begin{abstract}
Background: Diabetes and illiteracy are common problems in developing countries. In studies on diabetes and cardiac risk factors, literacy level, especially illiteracy, is not adequately addressed. Coronary heart disease (CHD) is a major complication of diabetes and the leading cause of premature death. The purpose of the study was to examine the relationship between literacy level and coronary risk factors in Non-Insulin Dependent Diabetes Mellitus (NIDDM) patients.
\end{abstract}

Methods: A cross-sectional study was conducted in an urban federally funded diabetic's clinic in Bandar Abbas, Iran. The sample consisted of 256 diabetic patients who were classified into three groups: Illiterates, low-literates and literates. The coronary risk factors were delimited to $\mathrm{HbA1C}, \mathrm{LDL}, \mathrm{HDL}$, total cholesterol (TC), Triglyceride (TG), Body Mass Index (BMI), and blood pressure.

Results: $67.5 \%$ of the patients were female, $42.1 \%$ illiterates, and $70 \%$ were overweight. The measures of TC and BMI were higher among females than males. Differences among the literacy levels based on LDL, TC, HDL, and TG were statistically significant.

Conclusion: According to our findings, literacy level does not have a role in glycemic control, but may affect LDL, HDL, TC and TG.

Keywords: Coronary risk factors; Diabetes; Glycated hemoglobin (HbA1C); Literacy

\section{Introduction}

Cardiovascular Disease (CVD) is the most common cause of mortality in urban industrial and developing countries [1]. Nearly 42.2\% daily deaths in Iran were due to CVD [2]. It is reported that CVD can be caused by diabetes and is a leading cause of premature death among people with Non-Insulin Dependent Diabetes Mellitus (NIDDM) [1]. In addition, NIDDM coexists with other conditions like obesity, dyslipidemia, atherosclerotic vascular disease, and hypertension [3]. The risk of CVD in people with NIDDM is between two and five times higher than it is for non-diabetic patients [4]. The major clinical objective in the management of NIDDM is to control hyperglycemia, and the long-term objective is to prevent micro vascular and macro vascular complications [5]

Dyslipidemia is an important risk factor for the development of CVD. Patients with diabetes are also found to have higher lipid values and a greater incidence of obesity and hypertension than patients without diabetes [6]. The incidence of CVD can be reduced by control of blood pressure (BP), lipid modification, and glycemic control [5]. Diabetes and illiteracy are serious problems in developing countries. In Iran, $2 \%$ of the population suffers from diabetes [7] and illiteracy level is estimated to be around $23 \%$ [2].

In studies of diabetes and cardiac risk factors, literacy/illiteracy is ignored. Literacy is defined as a functional and context-specific skill that includes oral skills (listening and speaking) and print-based skills (reading and writing) [8]. Studying the relationship between literacy and health is important to 1) better understand the true etiology of poor health outcomes; 2 ) identify a potential clinical marker of patients at risk for poor outcomes; and 3) develop effective interventions [9].

Improved glycemic control $(\mathrm{HbA} 1 \mathrm{C}<7 \%)$ reduces the risk of diabetic complications and mortality [10]. A study demonstrated that poor glycemic control was prevalent among patients with low literacy
[11]. However, another study reported Diabetes-related knowledge is often not strongly associated with glycemic control [12].

To examine the relationship between literacy level and coronary risk factors in NIDDM patients, we measured HbA1C, lipid profile, Body Mass Index (BMI), and blood pressure. Results from this study can help future interventions to improve diabetes outcomes among patients with different literacy levels.

\section{Methods}

A cross-sectional study was conducted in an urban federallyfunded diabetics clinic with 1400 registered diabetes patients in Bandar Abbas, a port city in south of Iran. The sample consisted of 256 NIDDM patients who had been diagnosed as being diabetic for at least one year prior to the conduct of the study by an internist. The subjects voluntarily agreed to participate in the study.

Based on the literacy level, patients were classified into three groups: 1) Illiterates, 2) low-literates (less than 7 years of schooling), and 3) literates (more than 7 years of schooling) $[9,13]$. The coronary risk factors were delimited to Glycated Hemoglobin (HbA1C), LDL, HDL, total cholesterol (TC), Triglyceride (TG), BMI, and blood pressure.

*Corresponding author: Jahanlou AS, Health Education Department, Hormozgan University of Medical Sciences; Bandar Abbas, Iran, Tel:+98 (76) 33337190, Fax: +98 (76) 33335009, Email: jahanlu@gmail.com or Alireza.Jahanlou@tamucc.edu

Received February 19, 2015; Accepted March 27, 2015; Published March 29 2015

Citation: Khademi M, Jahanlou S (2015) The Relationship between Literacy Level and Coronary Risk Factors in Diabetic Patients. J Gerontol Geriat Res 4: 209. doi:10.4172/2167-7182.1000209

Copyright: @ 2015 Khademi M, et al. This is an open-access article distributed under the terms of the Creative Commons Attribution License, which permits unrestricted use, distribution, and reproduction in any medium, provided the original author and source are credited. 
Metabolic control was assessed by measuring $\mathrm{HbA1C}$. To do that, we used colorimetric method. According to this method, in diabetic patients, $\mathrm{HbAlC}<7$ indicates good control, 7- 9 is fair control, and $>9$ represents bad (poor) control [14]. Total HDL, TG, and HbAlC were measured in fasting conditions by standard enzymatic methods. LDL was calculated indirectly according to Friedwald (TC- HDL- TG/5), excluding patients with TG $>4.5 \mathrm{mmol} / \mathrm{L}(400 \mathrm{mg} / \mathrm{dL})$ because the formula is not reliable in the presence of marked hyper-triglyceridemia.

Systolic and Diastolic BP was the mean of two measurements in sitting position by mercury sphygmomanometer after at least 20 minutes of rest, using the appropriate cuff size.

Body weight was measured to the nearest $0.1 \mathrm{~kg}$ on a scale with attached height measure. BMI was calculated as weight $/$ height ${ }^{2}\left(\mathrm{~kg} / \mathrm{m}^{2}\right)$ and obesity was defined as BMI $\geq 30 \mathrm{~kg} / \mathrm{m}^{2}$. Smokers were categorized as either current smokers, independent of the number of cigarettes per day, never smokers, or previous smokers (quitting tobacco for at least 6 months prior to the study) [15].

Analysis of data included one-way analysis of variance, Tukey's HSD post hoc procedure, and bivariate associations. The level of significance was set, a priori, at 0.05 . The Statistical Package for the Social Sciences (SPSS) was employed for the purpose of data entry entry, manipulation, and analysis.

\section{Results}

The majority of the subjects $(67.5 \%)$ were female and married (70\%). The mean age was $49.15 \pm 9.5$ years old, ranging from 27 to 72 . Nearly $70 \%$ of the patients were overweight with BMI of more than 25 . The duration of diabetes ranged from 1 to 30 years $(6.33 \pm 5.12)$. The majority (81.5\%) used oral anti-diabetics and diet (OAD) to control the disease, followed by $13.7 \%$ who used insulin and diet, and $4.8 \%$ who only relied on diet. Analysis of the data showed that with the exception of TC and BMI in which females significantly scored higher than did males, none of the gender differences was statistically significant. Results are summarized in Table 1.

\begin{tabular}{|c|c|c|c|c|}
\hline Variables & $\begin{array}{l}\text { Overall, } \\
\mathrm{N}=256\end{array}$ & $\begin{array}{c}\text { Males } \\
\mathrm{N}=83 \\
(32.5 \%)\end{array}$ & $\begin{array}{c}\text { Females } \\
N=173 \\
(67.5 \%)\end{array}$ & p \\
\hline Age (years) & $49.15 \pm 9.6$ & $51 \pm 9.7$ & $48 \pm 9.48$ & NS \\
\hline Elders ( $\geq 65$ years) $(\%)$ & 7.9 & 9.8 & 7.2 & NS \\
\hline Active smokers (\%) & 14.4 & 14.6 & 14.3 & NS \\
\hline Systolic BP (mmHg) & $129 \pm 21$ & $127 \pm 21^{*}$ & $132 \pm 21$ & NS \\
\hline Diastolic BP (mmHg) & $85 \pm 12$ & $\begin{array}{l}85 \pm 13 \\
(60-140)\end{array}$ & $85 \pm 11$ & NS \\
\hline Total cholesterol (mg/dL) & $207 \pm 43$ & $191 \pm 36$ & $215 \pm 44$ & $<0.05$ \\
\hline $\begin{array}{l}\text { Hyper- cholesterolemia(\%) } \\
\text { High risk (chol. } \geq 253 \mathrm{mg} / \mathrm{dl} \text { ) }\end{array}$ & 24.1 & 7.7 & 32.5 & $<0.05$ \\
\hline LDL cholesterol (mg/dL) & $124 \pm 37$ & $119 \pm 40$ & $127 \pm 35$ & NS \\
\hline High LDL cholesterol (\%) & 15.4 & 12.1 & 17.3 & NS \\
\hline HDL cholesterol (mg/dl) & $44 \pm 10.3$ & $42 \pm 10.7$ & $46 \pm 9.9$ & NS \\
\hline $\begin{array}{l}\text { Low-HDL cholesterol }(\%) \\
\text { (low HDL chol } \leq 35 \mathrm{mg} / \mathrm{dl} \text { ) }\end{array}$ & 30.1 & 51.5 & 18.3 & NS \\
\hline Serum triglycerides $(\mathrm{mg} / \mathrm{dL})$ & $\begin{array}{l}200 \pm 94.8 \\
(58-493)\end{array}$ & $\begin{array}{l}186 \pm 90 \\
(58-441)\end{array}$ & $\begin{array}{l}208 \pm 96 \\
(90-493)\end{array}$ & NS \\
\hline High triglycerides (\%) & 37.4 & 33.3 & 39.5 & NS \\
\hline $\mathrm{BMI}\left(\mathrm{kg} / \mathrm{m}^{2}\right)$ & $27.9 \pm 5.4$ & $25.7 \pm 3.5$ & $29.1 \pm 5.88$ & $<0.05$ \\
\hline Obesity (\%) & 34.7 & 12.5 & 45.7 & NS \\
\hline $\mathrm{HbA1c}$ & $\begin{array}{l}8.37 \pm 2.14 \\
(4.2-17.6)\end{array}$ & $\begin{array}{c}8.16 \pm 1.93 \\
(4.6-13)\end{array}$ & $\begin{array}{l}8.4 \pm 2.25 \\
(4.2-17.6)\end{array}$ & NS \\
\hline
\end{tabular}

Table 1: A Profile of the subjects.

\begin{tabular}{|c|c|c|c|}
\hline Behavior & Total patients & Illiterate & Low literate \\
\hline Smoking & $N(\%)$ & $\mathrm{N}(\%)$ & $N(\%)$ \\
\hline No & 214 (83.5) & $88(81.4)$ & $84(84)$ \\
\hline Yes & $42(16.5)$ & $20(18.6)$ & $16(16)$ \\
\hline \multicolumn{4}{|l|}{ Exercise } \\
\hline Always & $138(53.9)$ & $53(49)$ & $53(53)$ \\
\hline Seldom & $30(11.71)$ & $12(11.11)$ & $10(10)$ \\
\hline Never & $88(34.39)$ & $43(39.89)$ & $37(37)$ \\
\hline \multicolumn{4}{|l|}{ Foot care } \\
\hline Yes & $94(36.71)$ & $27(25)$ & $44(44)$ \\
\hline No & $162(63.29)$ & $81(75)$ & $56(56)$ \\
\hline \multicolumn{4}{|c|}{ Weight monitoring } \\
\hline No & $137(53.35)$ & $78(72.2)$ & $49(49)$ \\
\hline Yes & $119(46.65)$ & $30(27.8)$ & $51(51)$ \\
\hline \multicolumn{4}{|c|}{ Compliance with dietary regimen } \\
\hline Always & $137(53.35)$ & $55(50.92)$ & $56(56)$ \\
\hline Seldom & $83(32.42)$ & $34(31.48)$ & $33(33)$ \\
\hline Never & $36(14.23)$ & $19(17.61)$ & $11(11)$ \\
\hline \multicolumn{4}{|c|}{ Adherence to treatment regimen } \\
\hline Always & $203(79.29)$ & $84(77.77)$ & $85(85)$ \\
\hline Often & $31(12.1)$ & $13(12.03)$ & $10(10)$ \\
\hline Never & $22(8.61)$ & $11(10.2)$ & $5(5)$ \\
\hline
\end{tabular}

Table 2: A Cross-tabulation of literacy level by behaviors.

The analysis of the literacy data showed that $42.1 \%$ of the subjects were illiterate, followed by $39 \%$ low literates, and $19 \%$ literate. Chisquare Test of Independence revealed that group differences on the basis of foot caring and weight monitoring were statistically significant and showed that the illiterates used both less frequently than did the other two groups. Results are summarized in Table 2. Additionally, group differences on the basis of LDL, TC, HDL, and TG were statistically significant; differences due to $\mathrm{HbAlC}, \mathrm{BMI}$, and $\mathrm{BP}$ were not statistically significant.

Pearson's product moment correlation coefficient was employed to examine the direction and magnitude of the bivariate associations among the study's variables. As can be seen in Table 3, the majority of the associations were not statistically significant.

On the basis of the National Cholesterol Education Program Adult Treatment Panel III criteria, the study participants were classified for Dyslipidemia [16]. The National Institute of Diabetes and Digestive and Kidney Diseases recommends as the best cholesterol to HDL ratio is 3.5:1 and below 5:1 as the goal. In our study, we found that $6.5 \%$ and $62 \%$ of the participants achieved these ratios. On the basis of the American Heart Association's classification, 22.2\% of the illiterates in our study had over borderline LDL and 35.4\% had high TC. Approximately, 50\% of the literates had low HDL and $44.4 \%$ of low literates had high TG. Results are summarized in Table 4.

\section{Discussion}

The guidelines for management of Diabetes Mellitus (DM) recommend intensive control of blood sugar in an attempt to reach the target of less than $7 \% \mathrm{HbAlC}$, which is associated with reduced morbidity and mortality $[17,18]$. In our study, only $30 \%$ of the patients reached this target, which is alarming. On the other hand, we did not find any relationship between literacy level and glycemic control, which is supported by other studies $[12,19,20]$ while Jahanlou, et al. [13] and Fisher [21] observed a moderate inverse relationship. The difference could be due to inclusion of illiterate patients in our study, while theirs was delimited to low literate and literate patients. Like DeWalt [22] 


\begin{tabular}{|c|c|c|c|c|c|c|c|c|c|}
\hline & & Age & BMI & $\begin{array}{l}\text { Duration of } \\
\text { diabetes }\end{array}$ & HbA1c & LDL & HDL & Chol & TG \\
\hline \multirow[t]{2}{*}{ Age } & $\begin{array}{l}\text { Pearson } \\
\text { correlation }\end{array}$ & 1 & & & & & & 1 & \\
\hline & Sig. (2-tailed) & & & & & & & & \\
\hline \multirow[t]{2}{*}{ BMI } & $\begin{array}{l}\text { Pearson } \\
\text { correlation }\end{array}$ & -0.124 & 1 & & & & & & \\
\hline & Sig. (2-tailed) & 0.177 & & & & & & & \\
\hline \multirow[t]{2}{*}{$\begin{array}{l}\text { Duration of } \\
\text { diabetes }\end{array}$} & $\begin{array}{l}\text { Pearson } \\
\text { correlation }\end{array}$ & $.293^{* *}$ & -0.016 & 1 & & & & & \\
\hline & Sig. (2-tailed) & 0.001 & 0.864 & & & & & & \\
\hline \multirow[t]{2}{*}{ HbA1c } & $\begin{array}{l}\text { Pearson } \\
\text { correlation }\end{array}$ & -0.059 & $-.253\left(^{* \star}\right)$ & 0.082 & 1 & & & & \\
\hline & Sig. (2-tailed) & 0.539 & 0.008 & 0.391 & & & & & \\
\hline \multirow[t]{2}{*}{ LDL } & $\begin{array}{l}\text { Pearson } \\
\text { correlation }\end{array}$ & 0.084 & -0.072 & 0.063 & 0.041 & 1 & & & \\
\hline & Sig. (2-tailed) & 0.429 & 0.503 & 0.555 & 0.705 & & & & \\
\hline \multirow[t]{2}{*}{ HDL } & $\begin{array}{l}\text { Pearson } \\
\text { correlation }\end{array}$ & -0.169 & 0.045 & 0.102 & -0.037 & 0.019 & 1 & & \\
\hline & Sig. (2-tailed) & 0.105 & 0.675 & 0.331 & 0.732 & 0.856 & & & \\
\hline \multirow[t]{2}{*}{ Chol } & $\begin{array}{l}\text { Pearson } \\
\text { correlation }\end{array}$ & -0.02 & 0.147 & 0.042 & 0.069 & $\left..643^{(* *}\right)$ & $.404\left({ }^{* *}\right)$ & 1 & \\
\hline & Sig. (2-tailed) & 0.831 & 0.121 & 0.656 & 0.478 & 0 & 0 & & \\
\hline TG & $\begin{array}{l}\text { Pearson } \\
\text { correlation }\end{array}$ & 0.082 & 0.129 & 0.057 & 0.05 & 0.021 & -0.056 & $.377\left(^{* *}\right)$ & 1 \\
\hline
\end{tabular}

Table 3: Correlation matrix. 


\begin{tabular}{|c|c|c|c|c|c|c|}
\hline \multicolumn{3}{|c|}{$\begin{array}{l}\text { Measure fasting lipoproteins } \\
\text { in } \mathrm{mg} / \mathrm{dL}\end{array}$} & \multirow{2}{*}{\begin{tabular}{|l|} 
Total \\
$43.1 \%$
\end{tabular}} & \multirow{2}{*}{\begin{tabular}{|c|} 
Patients \\
43.8
\end{tabular}} & \multirow{2}{*}{\begin{tabular}{|c|} 
Illiterate low \\
44.7
\end{tabular}} & \multirow{2}{*}{\begin{tabular}{|r} 
Literate \\
38.1
\end{tabular}} \\
\hline & $<200$ & Desirable & & & & \\
\hline & $200-239$ & $\begin{array}{c}\text { Borderline } \\
\text { high }\end{array}$ & $32.8 \%$ & 20.8 & 34 & 57.1 \\
\hline \multicolumn{7}{|l|}{ TC } \\
\hline & $\geq 240$ & High & $24.1 \%$ & 35.4 & 21.3 & 4.8 \\
\hline & $<100$ & Optimal & 24.2 & 13.9 & 33.3 & 26.3 \\
\hline & $100-129$ & $\begin{array}{l}\text { Near } \\
\text { optimal/ } \\
\text { above } \\
\text { optimal }\end{array}$ & 37.4 & 44.4 & 33.3 & 31.6 \\
\hline \multicolumn{7}{|l|}{ LDL } \\
\hline & $130-159$ & $\begin{array}{c}\text { Borderline } \\
\text { high }\end{array}$ & 23.1 & 19.4 & 25 & 26.3 \\
\hline & $160-189$ & High & 11 & 13.9 & 5.6 & 15.8 \\
\hline & $\geq 190$ & Very high & 4.4 & 8.3 & 2.8 & 0 \\
\hline & $<40$ & Low & $30.1 \%$ & 19.4 & 22.4 & 50 \\
\hline & $\geq 60$ & High & $7.5 \%$ & 2.8 & 13.5 & 5 \\
\hline \multicolumn{7}{|l|}{ HDL } \\
\hline & $<150$ & Desirable & $35.7 \%$ & 33.3 & 31.1 & 50 \\
\hline & $150-199$ & $\begin{array}{c}\text { Borderline } \\
\text { high }\end{array}$ & $27 \%$ & 31.3 & 24.4 & 22.7 \\
\hline \multicolumn{7}{|l|}{ TG } \\
\hline & $200-499$ & High & $37.4 \%$ & 35.4 & 44.4 & 27.3 \\
\hline & $\geq 500$ & Very high & 0 & 0 & 0 & 0 \\
\hline \multicolumn{3}{|c|}{$\begin{array}{l}\text { TC: Total Cholesterol; LDL: } \\
\text { Lipoprotein; } \\
\text { TG: Triglyceride }\end{array}$} & \multicolumn{3}{|c|}{ Low-Density Lipoprotein; HDL } & L: High-Densi \\
\hline
\end{tabular}

Table 4: Subjects' Classification of Dyslipidemia According to National Cholesterol Education Program Adult Treatment Panel III, $\mathrm{n}=256$.

study, we did not find any statistically significant differences among literacy levels on the basis of literacy level [15].

It is reported that CHD is the leading cause of mortality in NIDDM patients [3]. Several factors contribute to the increased propensity toward premature atherosclerosis in diabetes. Alterations in serum lipoprotein pattern are one of them. Abnormalities in serum lipids, particularly in LDL, must be carefully evaluated to establish the individual CHD risk profile. In our study, only $13.9 \%$ of the patients had achieved an optimal level of LDL. On the basis of the National Cholesterol Education Program [23] (NCEP) standards, in the current study, only $2.2 \%$ of patients had LDL less than $70 \mathrm{mg} / \mathrm{dl}$ and $35.7 \%$ of patients had TG level less than $150 \mathrm{mg} / \mathrm{dl}$. The NCEP Adult Treatment Panel recommends that management of lipid abnormalities be based primarily on LDL level and this recommendation was endorsed by the American Diabetes Association [24].

Based on the classification criteria proposed by the American Heart Association [25], we found that $22.2 \%$ of illiterate patients had over the borderline LDL and $35.4 \%$ had high TC; $50 \%$ of literates had low HDL and $44.4 \%$ of low literates had high TG. According to the CSIRO classification [21], having a cholesterol level greater than $6.5 \mathrm{mmol} / \mathrm{L}$ (253 mg/dL), HDL cholesterol level less than $0.9 \mathrm{mmol} / \mathrm{L}$ ( $35 \mathrm{mg} / \mathrm{dL})$, and TG level greater than $2.3 \mathrm{mmol} / \mathrm{L}(204 \mathrm{mg} / \mathrm{dL})$ can increase the risk of CHD. None of the subjects in our study met these criteria.

A number of recent studies on individuals with diabetes indicate that in addition to maintaining optimal glucose levels, aggressive $\mathrm{CHD}$ risk factor control is critical for reducing the risk of CHD [26]. In our study, illiterates had high levels of total cholesterol and LDL without maintaining optimal glucose level, indicating that such patients are in high risk of CHD. On the other hand, $50 \%$ of the literates had low HDL without optimal glucose level and $44.4 \%$ of the low literates had high TG level without optimal glucose level. These findings suggest that the perception of "glycemic control" and "hyperglycemia reduction" is low in patients, especially among the illiterates. Awareness of CHD risk factors has been positively related to the desire to make risk-reducing behavioral changes [27]. The perceptions of personal risk for a disease may be an important factor in developing preventive health behaviors [28] and evidence supporting risk perception as the first step toward desired health behavior [29].

According to our findings, literacy level does not have a role in glycemic control, but may affect LDL, HDL, TC and TG. Due to crosssectional nature of our study, it is possible that some of the variables we examined would be related to longitudinal outcomes such as changes in $\mathrm{HbA1C}$.

\section{Suggestions for Further Research}

Future studies may evaluate other treatment variables that may help explain the pathways toward good diabetes outcomes. Further research is needed to develop a literacy sensitive instrument that takes into consideration the knowledge variations and the specific needs of the diabetics.

\section{Acknowledgements}

This research was funded by Vice Chancellor for Research in Tarbiat Modares University (Tehran, Iran). We are greatly indebted to all general practitioners whose assistance made the conduct of the study possible. Special thanks to Drs. A. Behzad and M. Affandi, Diabetic Clinic Centre, and Dr M. Porkiani, Vice Chancellor for Treatment at Hormozgan University of Medical Sciences. We would also like to thank managers and staff of Diabetic Clinic Center for their help and cooperation.

\section{References}

1. Fakhrzadeh $\mathrm{H}$, Bandarian $\mathrm{F}$, Adibi $\mathrm{H}$, Samavat $\mathrm{T}$, Malekafzali $\mathrm{H}$, et al. (2008) Coronary heart disease and associated risk factors in Qazvin: a populationbased study. East Mediterr Health J 14: 33-41.

2. World Health Organization (2006) Country cooperation strategy at a glance (2006) World Health Organization. Youth Violence and Alcohol. World Health Organization.

3. Branchi A, Rovellini A, Torri A, Sommariva D (1998) Accuracy of calculated serum low-density lipoprotein cholesterol for the assessment of coronary heart disease risk in NIDDM patients. Diabetes Care 21: 1397-1402.

4. Elkeles RS, Godsland IF, Rubens MB, Feher MD, Nugara F, et al. (2008) The progress of coronary heart disease in Type 2 diabetes as measured by coronary calcium score from electron beam computed tomography (EBCT): the PREDICT study. Atherosclerosis 197: 777-783.

5. Palumbo PJ (1998) Metformin: effects on cardiovascular risk factors in patients with non-insulin-dependent diabetes mellitus. J Diabetes Complications 12 : 110-119.

6. Chan DT, Irish AB, Dogra GK, Watts GF (2008) Dyslipidaemia and cardiorenal disease: mechanisms, therapeutic opportunities and clinical trials. Atherosclerosis 196: 823-834.

7. Jahanlou AS, Ghofranipour F, Kimmiagar M, Vafaei M, Heydarnia A, et al (2011) Can quality of life questionnaires be used in diabetics to assess the relation between $\mathrm{HbA} 1 \mathrm{c}$ and patients' domain aspects? Acta Med Iran 49: 246251.

8. Katz MG, Jacobson TA, Veledar E, Kripalani S (2007) Patient literacy and question-asking behavior during the medical encounter: a mixed-methods analysis. J Gen Intern Med 22: 782-786.

9. DeWalt DA, Hink A (2009) Health literacy and child health outcomes: a systematic review of the literature. Pediatrics 124 Suppl 3: S265-274. 
Citation: Khademi M, Jahanlou S (2015) The Relationship between Literacy Level and Coronary Risk Factors in Diabetic Patients. J Gerontol Geriat Res 4: 209. doi:10.4172/2167-7182.1000209

10. Inoue K, Matsumoto M, Kobayashi $Y$ (2007) The combination of fasting plasma glucose and glycosylated hemoglobin predicts type 2 diabetes in Japanese workers. Diabetes Res Clin Pract 77: 451-458.

11. Schillinger D, Grumbach K, Piette J, Wang F, Osmond D, et al. (2002) Association of health literacy with diabetes outcomes. JAMA 288: 475-482.

12. Rothman RL, Malone R, Bryant B, Shintani AK, Crigler B, et al. (2005) A randomized trial of a primary care-based disease management program to improve cardiovascular risk factors and glycated hemoglobin levels in patients with diabetes. The American journal of medicine 118: 276-284.

13. Jahanlou AS, Alishan Karami N (2011) The effect of literacy level on health related-quality of life, self-efficacy and self-management behaviors in diabetic patients. Acta Med Iran 49: 153-158

14. Basa RP, McLeod B (1995) Evaluation of a diabetes specialty centre: structure process and outcome. Patient Educ Couns 25: 23-29.

15. NATIONAL Institutes of Health. Third Report of the National Cholesterol Education Program Expert Panel on detection, evaluation, and treatment of high blood cholesterol in adults (Adult Treatment Panel III). Executive Summary. Bethesda, MD, National Institutes of Health, National Heart, Lung and Blood Institute 2001(NIH publ. no. 01-3670).

16. Centers for Disease Control and Prevention (CDC), \& Centers for Disease Control and Prevention (CDC) (2011) National diabetes fact sheet: national estimates and general information on diabetes and prediabetes in the United States, Atlanta, GA: US Department of Health and Human Services, Centers for Disease Control and Prevention, 201.

17. Reaven GM (2002) Multiple CHD risk factors in type 2 diabetes: beyond hyperglycaemia. Diabetes Obes Metab 4 Suppl 1: S13-18.

18. Qari FA (2005) Glycemic and good target control among diabetics at a university and Erfan private hospital. Turkish J Endocrinol Metab 2: 49-54.
19. Williams MV, Baker DW, Parker RM, Nurss JR (1998) Relationship of functional health literacy to patients' knowledge of their chronic disease: a study of patients with hypertension and diabetes. Archives of internal medicine 158: 166-172.

20. Morris NS, MacLean CD, Littenberg B (2006) Literacy and health outcomes: a cross-sectional study in 1002 adults with diabetes. BMC Fam Pract 7: 49.

21. Fisher $E$ (1999) Low literacy levels in adults: implications for patient education. $\mathrm{J}$ Contin Educ Nurs 30: 56-61.

22. DeWalt DA, Boone RS, Pignone MP (2007) Literacy and its relationship with self-efficacy, trust, and participation in medical decision making. Am J Health Behav 31 Suppl 1: S27-35.

23. Grundy SM, Cleeman JI, Merz CNB, Brewer HB, Clark LT, et al. (2004) Implications of recent clinical trials for the national cholesterol education program adult treatment panel III guidelines. Journal of the American College of Cardiology 44: 720-732

24. Baghurst K, Record S, Leppard P (2000) Red meat consumption in Australia: intakes, nutrient contribution and changes over time. Australian Journal of Nutrition and Dietetics 57: 36

25. The MERCK Manuals (2013) online medical library, for healthcare professionals

26. American Diabetes Association (2006) Standards of medical care in diabetes--2006. Diabetes Care 29 Suppl 1: S4-42.

27. Winkleby MA, Flora JA, Kraemer HC (1994) A community-based heart disease intervention: predictors of change. Am J Public Health 84: 767-772.

28. King KB, Quinn JR, Delehanty JM, Rizzo S, Eldredge DH, et al. (2002) Perception of risk for coronary heart disease in women undergoing coronary angiography. Heart Lung 31: 246-252.

29. Green JS, Grant M, Hill KL, Brizzolara J, Belmont B (2003) Heart disease risk perception in college men and women. J Am Coll Health 51: 207-211. 